\title{
Peptides complementary to the active loop of porin P2 from Haemophilus influenzae modulate its activity
}

This article was published in the following Dove Press journal:

International Journal of Nanomedicine

9 May 2012

Number of times this article has been viewed

\author{
Marco Cantisani' \\ Mariateresa Vitiello² \\ Annarita Falanga' \\ Emiliana Finamore ${ }^{2}$ \\ Marilena Galdiero ${ }^{2}$ \\ Stefania Galdiero' \\ 'Department of Biological Sciences, \\ CIRPeB and IBB CNR, University \\ of Naples "Federico II," Napoli, \\ Italy; ${ }^{2}$ Department of Experimental \\ Medicine, II University of Naples, \\ Napoli, Italy
}

\begin{abstract}
Haemophilus influenzae type b (Hib) is one of the leading causes of invasive bacterial infection in young children. It is characterized by inflammation that is mainly mediated by cytokines and chemokines. One of the most abundant components of the Hib outer membrane is the $\mathrm{P} 2$ porin, which has been shown to induce the release of several inflammatory cytokines. A synthetic peptide corresponding to loop L7 of the porin activates JNK and p38 mitogenactivated protein kinase (MAPK) pathways. We report a novel use of the complementary peptide approach to design a peptide that is able to bind selectively to the protein $\mathrm{P} 2$, thereby reducing its activity. This work provides insights into essential molecular details of $\mathrm{P} 2$ that may affect the pathogenesis of Hib infections where interruption of the signaling cascade could represent an attractive therapeutic strategy.
\end{abstract}

Keywords: complementary-peptide, rational design, porin

\section{Introduction}

Peptide-peptide interactions play a fundamental role in cellular processes. ${ }^{1,2}$ De novo designed peptide ligands aimed at particular binding sites on target proteins can lead to a better understanding of this kind of molecular interaction ${ }^{3}$ and allow the discovery of novel therapeutics. An effective way to design functional peptide ligands is the antisense peptide approach.

Antisense peptides, defined as peptides coded by antisense (negative) strands of DNA, are able to interact specifically with the sense peptide in a way that is comparable to the specific interaction between the sense and complementary strands of DNA. Several sense and antisense peptide pairs have been reported to bind to each other, ${ }^{4}$ which might be correlated to the fact that the antisense peptide is the hydropathic complement of the native sequence. ${ }^{5}$ There have been numerous reports of the successful identification of peptide-peptide interactions based on these principles. ${ }^{6-14}$ However, the mechanism of interactions is still debated under two main hypotheses. In the molecular recognition theory (MRT), the sense and complementary strands of DNA must always code for peptide sequences that are opposite in hydropathic profile to each other, and therefore have mutually complementary shapes, so they should be able to interact specifically. ${ }^{5,15}$ In the Mekler-Idlis (M-I) pair theory, ${ }^{12}$ each amino acid in a sense peptide interacts with its corresponding codon-directed amino acid residue in an antisense peptide in a specific and pair-wise way. Owing to the degeneracy of genetic codes, each given amino acid residue is coupled to more than one amino acid residue. Accordingly, there is more than one antisense peptide corresponding to a defined sense peptide, which is called the degeneracy of antisense peptide. Both theories 
provide new insight into the design and selection of antisense peptides with a strong affinity for sense peptides. ${ }^{16}$

The treatment of bacterial infections with antibiotics is one of the key concepts of human medicine. However, the effectiveness of antibiotics has become limited owing to an increase in bacterial antibiotic resistance, which presents a global health problem with a strong social and economic impact. Thus, there is an urgent need for the development of antibiotics with a novel mechanism of action. Bacterial pathogenicity is largely dependent on its surface structures. Among the components of the bacterial outer membrane, outer membrane proteins (OMPs), such as the porins, play a fundamental role in pathogenicity and in protection. ${ }^{17}$

Haemophilus influenzae, a Gram-negative bacterium belonging to Pasteurellaceae, is responsible for a variety of infections in humans and animals, which range from local respiratory infections to serious invasive diseases. Thus, an understanding of the structure-function relationships of Haemophilus influenzae type b (Hib) components may provide opportunities to develop novel antibacterial agents.

Bacterial surfaces are important when considering the interaction with host cells and tissues in the context of pathogenesis and immunity. The identification of surface components may highlight domains that are likely to be involved directly in the interaction with the host ${ }^{18}$ and may be critical for reducing the number of targets for the design of potential vaccines. A key component of the Gram-negative bacterial outer membrane, porins play an important role in pathogenesis of bacterial infections, and stimulate immunological responses inducing the release of several cytokines. ${ }^{18,19}$ Structural analyses have revealed that bacterial porins exist as homotrimers of intimately associated subunits. The folding pattern of each monomer is constituted by 16 or 18 anti-parallel $\beta$-strands crossing the outer membrane and loops that connect the $\beta$-strands on either side of the membrane. The whole structure is an anti-parallel $\beta$-barrel with eight large loops of variable length on the external surface of the bacterial membrane and eight short periplasmic turns. ${ }^{20}$ This tight conformation, inserted into the outer membrane, forms a compact molecule with cellsurface-exposed domains involved in various activities. ${ }^{20}$ The importance of surface-exposed loops of porins has been the focus of recent studies. ${ }^{21}$ Some of the surface-exposed loops are involved in the recognition of ligands, including small molecule nutrients, agents such as bacteriophages or colicins, and probably eukaryotic target cells for bacterial pathogens.
Porin $\mathrm{P} 2$ of $\mathrm{Hib},{ }^{22}$ one of the best-characterized porins in terms of its functional characteristics, is the most abundant OMP in nontypeable $H$. influenzae (NTHi) and in Hib. Its molecular mass varies between 36 and $42 \mathrm{kDa}$, and it is present in all strains and functions as a porin. ${ }^{22} \mathrm{P} 2$ contains 16 anti-parallel $\beta$ strands across the outer membrane, eight large loops of variable length on the external surface of the bacterial membrane, and eight short periplasmic turns ${ }^{21}$ (Figure 1A). All transmembrane regions are relatively conserved among strains, while considerable heterogeneity exists in loop regions. ${ }^{21}$ The $\beta$-barrel spans the entire outer membrane, forming a trimer with the three-barrel axes almost mutually parallel and perpendicular to the membrane. With regard to other porins, one large loop (loop L3), folding back into the channel, determines effective pore cross section and consequent molecular exclusion limit, as well as its physiological and conductivity properties. ${ }^{21}$

Recently, it has been demonstrated that porin P2 from Hib induces activation of signaling pathways in U937 cells through the MEK1-MEK2/MAPK cascade. ${ }^{21,23,24}$ Peptide sequences corresponding to variable loop regions facing the cell exterior are able to activate this cascade and provide mitogen-activated protein kinase (MAPK) pathway activation similar to that of the entire porin. In particular, we have reported that a synthetic peptide (L7) corresponding to loop 7 of protein P2 is mainly responsible for the activation of MEK1/MEK2/MAPK signaling pathways. We also investigated the role of synthetic peptide L7 of porin P2 in an experimental model in the initial phase of systemic inflammation and coagulation responses in vivo. We found that L7 significantly induces pathophysiological changes on both hemodynamic and coagulation parameters, and observed a modification of the circulating markers of endothelial injury during Gram-negative bacterial sepsis. $^{25}$

Agents that interfere with ligand binding and/or the formation of the higher order complexes would clearly have therapeutic potential and/or be useful biological tools. In this context, biological active peptides might be developed as specific antagonist of loop L 7 and serve as useful tools in the drug discovery process. In this study, we designed peptides complementary to loop L7, which may be used to block the activity of the porin and may provide new opportunities to the design of novel agents that could be added to the existing therapeutic options in order to obtain complete coverage. This strategy may represent a novel approach for the design of antibacterial drugs that could be used against a wide range of Gram-negative bacteria (Figure 1B). 
A

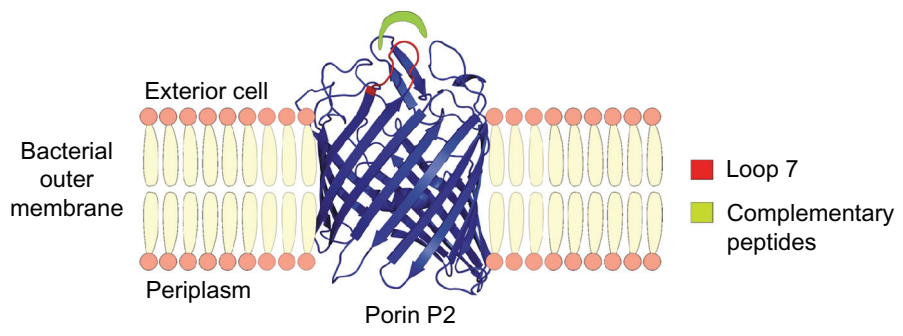

B

Activation of signal transduction pathways by porin P2

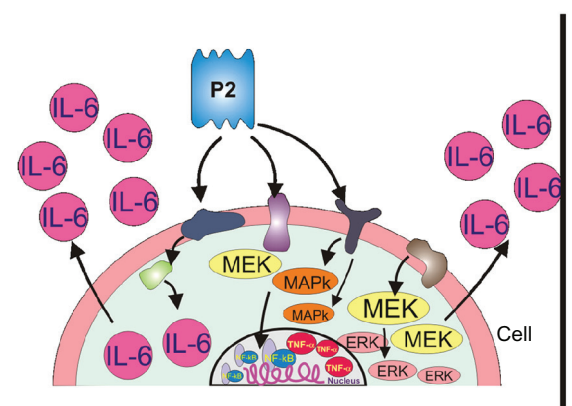

Reduced activation in presence of complementary peptides

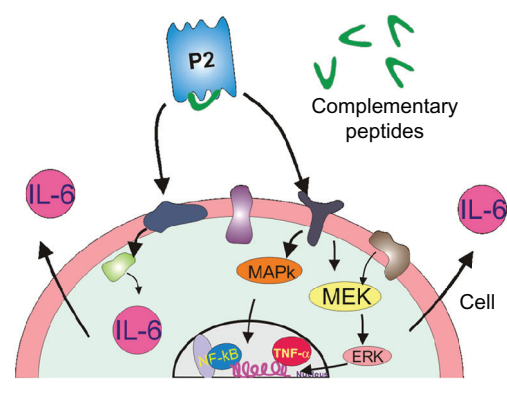

C Hydropathic plot of loop 7 and its complementary peptide
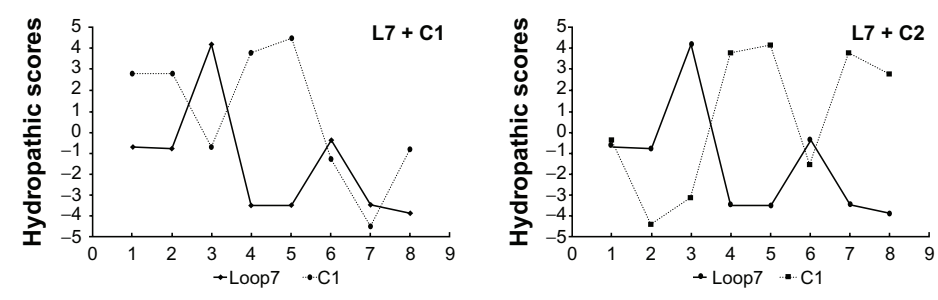

Amino acids

Amino acids

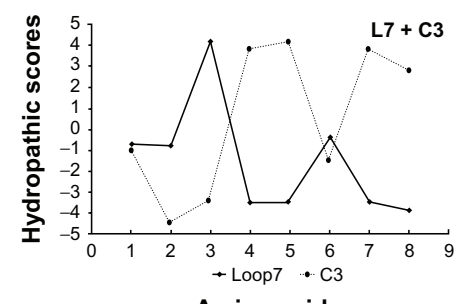

Amino acids

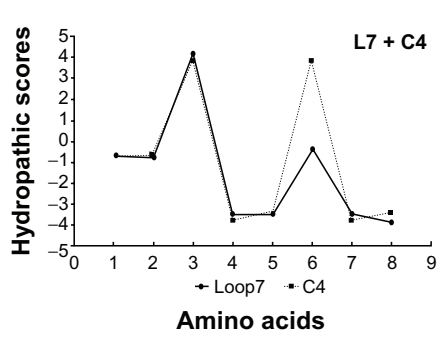

Figure I Three dimensional model of the P2 monomer from Hib (panel A) showing the target of our study, loop L7; signal transduction pathways analyzed in this study and their inhibition with complementary peptides (panel B); Kyte-Doolittle hydropathy plots of L7 and complementary peptides (panel C).

\section{Materials and methods}

\section{Cell lines}

U937 monocytes (ATCC CRL-1593.2) were grown and differentiated as previously described. ${ }^{26}$

\section{Bacteria and growth conditions}

H. influenzae type b (Hib), (ATCC 9795), and Salmonella enterica serovar Typhimurium (strain SH5014) were grown in CY medium and nutrient broth (Difco), respectively, for
18-24 hours at $37^{\circ} \mathrm{C}$. Cells were harvested at the end of the exponential growth phase.

\section{Preparation of Hib and Salmonella OmpC Porins}

Hib and OmpC porins were isolated and purified from bacterial cells as previously reported. ${ }^{27,28}$ The protein content of the porin preparation was determined by the method of Lowry et $\mathrm{al}^{29}$ and checked by SDS-PAGE according to Laemmli. ${ }^{30}$ All possible 
traces of LPS (lipopolysaccharides) were revealed on SDS-PAGE stained with silver nitrate as described by Tsai and Frasch $^{31}$ and by the Limulus-amoebocyte-lysate assay (Limulus test) according to Yin et al. ${ }^{32}$ Using the Limulus test, LPS contamination in the porin preparation was estimated to be about $0.001 \% \mathrm{w} / \mathrm{w}$. The pore-forming ability of our preparation was checked by a functional assay (liposome swelling assay) after the incorporation into proteoliposome according to Nikaido and Rosenberg. ${ }^{33}$

\section{Peptide synthesis}

Peptides (Table 1) were synthesized using the standard solidphase 9-fluorenylmethoxycarbonyl (FMOC) method and purified as reported previously. ${ }^{21,23}$ All purified peptides were obtained with good yields $(70 \%-80 \%)$ and a purity $>95 \%$. A scrambled peptide, with the same composition, but a different sequence from L7, was also synthetized as a control to state the sequence-dependency of the results.

Nitrobenzoxadiazolo (NBD) labelling was performed on resin-bound peptides as previously reported by Rapaport and Shai. ${ }^{34}$ The identity of the NBD-peptides was confirmed by LC/MS. All the peptides were detoxified before being tested on cells. Detoxification was performed by using Detoxi Gel ${ }^{\mathrm{TM}}$ Affinity Pak columns supplied by Pierce (Rockford, Il). ${ }^{35}$

\section{Analysis of kinase phosphorylation}

U937 cells $\left(3 \times 10^{6}\right.$ cells $\left./ \mathrm{mL}\right)$ were stimulated by different concentrations of stimuli for different periods. In some experiments, the complementary peptides $\mathrm{C} 1, \mathrm{C} 2, \mathrm{C} 3$, and $\mathrm{C} 4$ were preincubated for 60 minutes at $37^{\circ} \mathrm{C}$ with Hib porin or loop L7 and then used for U937-stimulation.

After incubation, the cells were prepared as previously reported $^{21}$ and used for enhanced chemiluminescence (ECL) Western blot analysis. Immunoprecipitation was carried out with the appropriate antibodies: (1) anti-phospho-p44/42 MAPK (Thr 202/Tyr 204) E10 monoclonal antibodies (isotype, mouse IgG1; anti-phospho-p44/42; New England Biolabs, Beverly, MA), which detects doubly phosphorylated

\section{Table I Peptide sequences}

\begin{tabular}{ll}
\hline Loop 7 & $\mathrm{NH} 2-\mathrm{T}-\mathrm{S}-\mathrm{V}-\mathrm{D}-\mathrm{Q}-\mathrm{G}-\mathrm{E}-\mathrm{K}-\mathrm{COOH}$ \\
Sense-RNA & $5^{\prime}-\mathrm{ACU}-\mathrm{UCU}-\mathrm{GUA}-\mathrm{GAU}-\mathrm{CAA}-\mathrm{GGU}-\mathrm{GAA}-\mathrm{AAA}-3^{\prime}$ \\
Antisense- & $3^{\prime}-\mathrm{UGA}-\mathrm{AGA}-\mathrm{CAU}-\mathrm{CUA}-\mathrm{GUU}-\mathrm{CCA}-\mathrm{CUU}-\mathrm{UUU}-5^{\prime}$ \\
RNA & \\
Cl & $\mathrm{COOH}-\mathrm{S}-\mathrm{R}-\mathrm{Y}-\mathrm{I}-\mathrm{L}-\mathrm{T}-\mathrm{F}-\mathrm{F}-\mathrm{NH}_{2}$ \\
$\mathrm{C} 2$ & $\mathrm{NH}_{2}-\mathrm{G}-\mathrm{R}-\mathrm{H}-\mathrm{L}-\mathrm{V}-\mathrm{P}-\mathrm{L}-\mathrm{F}-\mathrm{COOH}$ \\
$\mathrm{C} 3$ & $\mathrm{NH}_{2}-\mathrm{W}-\mathrm{R}-\mathrm{Q}-\mathrm{L}-\mathrm{V}-\mathrm{P}-\mathrm{L}-\mathrm{F}-\mathrm{COOH}$ \\
$\mathrm{C} 4$ & $\mathrm{NH}_{2}-\mathrm{S}-\mathrm{T}-\mathrm{L}-\mathrm{K}-\mathrm{N}-\mathrm{L}-\mathrm{K}-\mathrm{E}-\mathrm{COOH}$ \\
Scrambled & $\mathrm{NH}_{2}-\mathrm{G}-\mathrm{V}-\mathrm{Q}-\mathrm{K}-\mathrm{S}-\mathrm{D}-\mathrm{T}-\mathrm{E}-\mathrm{COOH}$ \\
\hline
\end{tabular}

Abbreviation: RNA, ribonucleic acid. threonine 202 and tyrosine 204 of p44 and p42 MAPKs (ERK1 and ERK2) and are produced by immunizing mice with a synthetic phospho-Thr202 and phospho-Tyr204 peptide corresponding to residues around Thr202 and Tyr204 of human p44 MAPK; (2) anti phospho-MEK1/2 antibody (anti-p-MEK1/2; New England Biolabs, Ipswich, MA), which detects MEK1/2 only when it is activated by phosphorylation at Ser217 and Ser221 and does not cross-react with other related family members; (3) anti-phospho-p38 antibody (Santa Cruz Biotechnology Inc, Santa Cruz, CA), which is a rabbit polyclonal antibody raised against a peptide mapping at the amino terminus of p38 of mouse origin identical to the corresponding human sequence and is directed against Thr180 and Tyr182-phosphorylated p38 (New England Biolabs); (4) anti-phospho-JNK antibody, which is a mouse monoclonal IgG1 antibody raised against a peptide corresponding to a short amino acid sequence phosphorylated on Thr183 and Tyr185 of JNK of human origin (Santa Cruz Biotechnology Inc). Blots were blocked for 1 hour at room temperature in Tris-buffered saline (TBS [150 mM NaCl, $20 \mathrm{mM}$ Tris-HCl, pH 7.5]) containing 1\% BSA (SigmaAldrich SRL, Milan, Italy) plus 1\% blotting grade blocker non-fat milk (Bio-Rad Laboratories, Hercules, CA). Membranes were subsequently washed twice with TBS containing $0.05 \%$ Tween-20 (TTBS) before incubation for 1 hour at room temperature with anti-phosphokinase antibodies (as described earlier) diluted in TBS containing $1 \%$ bovine serum albumin (BSA). After six washings with TTBS for 3 minutes, polyvinylidene difluoride (PVDF) membranes were incubated at room temperature for 2 hours with anti-mouse or anti-rabbit immunoglobulin $\mathrm{G}$ (IgG) horseradish peroxidase-linked (HRP) secondary antibodies diluted 1:3.000.

\section{Enzyme-linked immunosorbent assay for cytokines}

All assays were carried out using $3 \times 10^{6} / \mathrm{mL}$ U937 cells stimulated with different concentrations of stimuli for 24 hours at $37^{\circ} \mathrm{C}$ in $5 \% \mathrm{CO}_{2}$ (time points and concentrations have been established in preliminary experiments and optimized for maximum release of cytokines). The complementary peptides $\mathrm{C} 1, \mathrm{C} 2, \mathrm{C} 3$, and $\mathrm{C} 4$ were preincubated for 60 minutes at $37^{\circ} \mathrm{C}$ with Hib or loop L7 and then used for U937 stimulation. The samples were centrifuged at $1800 \mathrm{rpm}$ at $4{ }^{\circ} \mathrm{C}$ for 10 minutes, and the supernatants were collected and stored at $-80^{\circ} \mathrm{C}$. TNF- $\alpha$ and IL- 6 release were measured by AviBion Human ELISA kits from Orgenium Laboratories (Vantaa, Finland), according to the manufacturer's recommendations. The assays employ an antibody specific for human TNF- $\alpha$ 
or IL-6 coated on a 96-well plate. Standards, samples, and biotinylated anti-human TNF- $\alpha$ or IL- 6 were pipetted into the wells, and TNF- $\alpha$ or IL-6 present in the samples were captured by the antibodies immobilized to the wells and by the biotinylated specific detection antibodies. All analyses were performed at least four times for each individual cellstimulation assay.

\section{AP-I and NF- $\kappa B$ activation analysis}

To detect and quantify AP-1 and NF- $\kappa$ B activation in U937 cells, we used ELISA-based Trans-Am ${ }^{\circledR}$ transcription factor kits (Active Motif, Carlsbad, CA).$^{36}$ The active forms of AP-1 c-Fos and c-Jun or NF-אB p50 and p65 subunits in whole-cell extracts can be detected using Abs specific for epitopes that are accessible only when the nuclear factors are activated and bound to their target DNA. U937 cells $\left(10 \times 10^{6} / \mathrm{mL}\right)$ were stimulated with the optimal amount of $\mathrm{Hib}$ porin or loop $\mathrm{L} 7$ for 1 hours at $37^{\circ} \mathrm{C}$ in $5 \% \mathrm{CO}_{2}$ as determined in the pilot assays. The complementary peptides $\mathrm{C} 1, \mathrm{C} 2, \mathrm{C} 3$, and $\mathrm{C} 4$ were preincubated for 60 minutes at $37^{\circ} \mathrm{C}$ with Hib porin or loop L7 and then used for U937 stimulation. Preparation of cell extract was done according to the manufacturer's instructions. Ten micrograms of proteins, collected after cell stimulation, was added to the wells. After a 1 hour incubation period at room temperature, the wells were washed three times with the washing buffer included in the kit; $100 \mu \mathrm{L}$ of the provided anti c-Fos and anti c-Jun or anti-p65 and anti-p50 antibodies was added at a 1:1000 dilution. The plate was incubated at room temperature for 1 hour and the wells were washed three times. HRP-conjugated anti-rabbit IgG was added at a 1:1000 dilution and incubated for 1 hour at room temperature. Samples were washed four times, and developing solution was added, followed by the stop solution. The amount of AP-1 or NF- $\mathrm{KB}$ activation was measured at $450 \mathrm{~nm}$ in an HTS 700 BioAssay reader (Perkin Elmer, Norwalk, CT). The specificity of the assays was checked by measuring the ability of soluble wildtype or mutated AP-1 or NF- $\mathrm{BB}$ oligonucleotides to inhibit binding. In preliminary assays, the Trans-Am kits showed a good correlation with an electrophoretic mobility shift assay (EMSA) in detecting the DNA binding capacity of AP-1 and NF- $\kappa$ B.

\section{Binding of complementary peptides to Porin $\mathrm{P} 2$ by gel filtration}

Peptides C1, C2, C3, C4, and L7 were dissolved in the equilibration buffer (Phosphate $20 \mathrm{mM}, \mathrm{pH} 7.5$ ). $100 \mu \mathrm{L}$ of a solutions $1.010^{-3} \mathrm{M}$ of peptide were mixed to $70 \mu \mathrm{L}$ of a solution containing porin P2 or porin OMPC $\left(3.510^{-4} \mathrm{M}\right)$, with a molar ratio $\mathrm{P} 2 /$ peptide of $1 / 40$. The peptide concentration of complementary peptides was chosen according to the minimal concentration of the NBD group that we were able to detect by UV in these experimental conditions. The binding mixture was held for 1 hour at $37^{\circ} \mathrm{C}$ and then was loaded on a PD-10 column containing Sephadex G-25 medium. The collected fractions were analyzed by UV spectrometry and the presence of the NBD moiety was determined.

\section{Lactate Dehydrogenase (LDH) assay}

The LDH assay was carried out according to the manufacturer's instructions by using a cytotoxicity detection kit (Roche Diagnostic SpA, Milan, Italy).

\section{Reproducibility}

Gels were scanned for densitometry analysis by Sigma Gel software (GeoMem Limited, Dundee, UK) and the results shown are an average of three different experiments. The results were expressed as the mean \pm standard deviation (SD) of three independent experiments.

\section{Results \\ Peptide design}

Double helical DNA is made of two antiparallel 2'-deoxypolynucleotide chains. It has been thought that the sense strand contains the coding information for proteins and peptides, whereas the antisense (complementary) strand propagates the information. Coding information may be obtained from the complementary strand as well; peptides coded for by sense and complementary strands of DNA are actually able to interact specifically similarly to the two strands of DNA. ${ }^{12}$ A complementary peptide is coded for by the nucleotide sequence $5^{\prime} \rightarrow 3^{\prime}$ (Mekler-Idlis direction) of the complementary strand of DNA (or, more precisely, by codons in complementary mRNA whose sequence contains the same coding information as the complementary strand of DNA $)^{5}$. The codons in complementary mRNA may also be read continuously in the $3^{\prime} \rightarrow 5^{\prime}$ (Root-Bernstein direction) to give an alternative complementary peptide (Table 1). ${ }^{12,37}$ Our approach has been to exploit this concept of complementary peptides in order to design peptides able to block the activity of the porin P2 from Hib. Therefore, we designed peptides complementary to one of the surface exposed loops (loop L7), which was involved in the interaction with the host cell. We thought that complementary peptides could interact specifically with the porin and reduce its biological activity. Three antisense peptides $(\mathrm{C} 1-\mathrm{C} 3)$ were designed based on the principle of complementary base pairs and the degeneracy of 
genetic codes (Table 1), using L7 as target sense peptide. The sense mRNA sequence of $\mathrm{L} 7$ was obtained and the sequence of $5^{\prime} \rightarrow 3^{\prime}$ complementary M-I peptide was deduced from the corresponding complementary mRNA sequence (Table 1, peptide $\mathrm{C} 1$ ). Using the Root-Bernstein theory, we also designed two $3^{\prime} \rightarrow 5^{\prime}$ complementary peptides of L7: C2 and $\mathrm{C} 3$. The original complementary mRNA-derived sequences of C2 and C3 were complicated by the appearance of a stop codon at the N-terminus. We substituted the stop codons with the other two complementary amino acids of threonine (tryptophan and cysteine). In particular, in C3, a tryptophan was substituted for the appearance of the stop signal, while in C2 a glycine was used as a substitute for cysteine to avoid any added complication from the thiol group oxidation as well racemization during synthesis.

As a control for the application of the sense and complementary peptide theory, we designed peptide C4 simply considering the characteristics of single residues, substituting the charged residues with analog residues with opposite charge and hydrophilic or hydrophobic residues with residues bearing similar features.

In the past, much research has reported on the fact that sense and complementary peptides are mutually complementary with respect to their hydropathic profiles (according to the Kyte-Doolittle scale $)^{38}$ and are, therefore, able to interact specifically on account of their mutually complementary shapes (secondary and tertiary structures). Figure $1 \mathrm{C}$ shows a hydropathic plot of L7 and each of the complementary peptides. In this plot, the complementary peptides $\mathrm{C} 1$, C2, and C3 showed evident complementarities with L7 in hydropathic scores; while the peptide C4 that was used as control showed a hydropathic profile similar to L7, which was as expected because the only differences concerned the charges of polar residues.

\section{MAPK pathway signaling activation by loop L7 and complementary peptides}

Having previously demonstrated ${ }^{21,23,24}$ that loop L7 was the most active among the peptides corresponding to external loops of porin P2 at inducing MEK1-MEK2/ MAPK pathways (in particular JNK and p38), we now compared activating phosphorylation capabilities of complementary peptides by individual tests on U937 cells (Figure 2).

U937 cells were treated with stimuli as described in the previous section. The optimal concentrations and time points of the stimulations were selected by experiments performed previously on porin P2 and peptide L7 and analogs. ${ }^{21,23}$
A

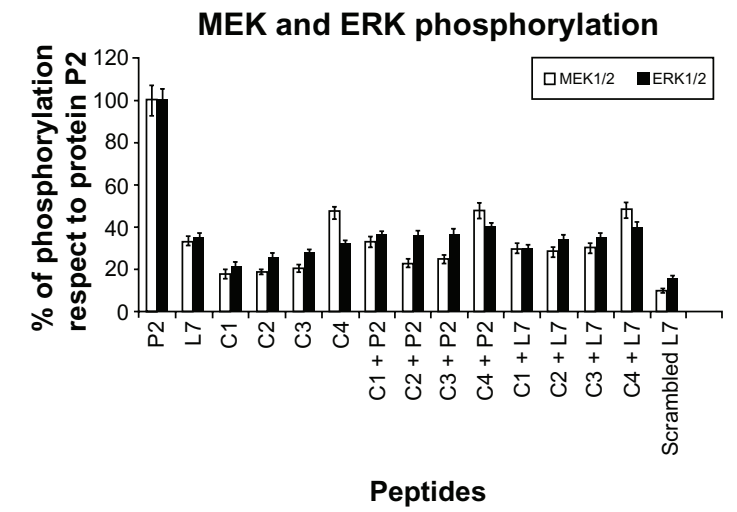

B

p38 and JNK phosphorylation

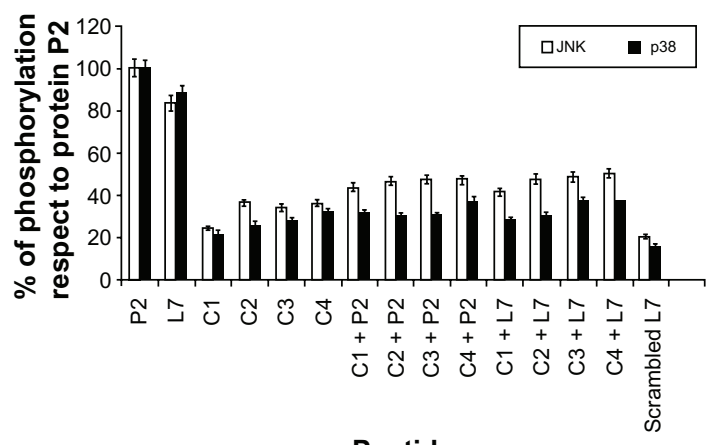

Peptides

Figure 2 MEKI-MEK-2/MAPK activation in U937 cells in response to Hib porin $(13 \mathrm{nmol} / \mathrm{ml})$ or peptides $(130 \mathrm{nmol} / \mathrm{mL})$. In some assays, the complementary peptides $\mathrm{Cl}, \mathrm{C2}, \mathrm{C} 3$ and $\mathrm{C} 4$ were preincubated for 60 minutes at $37^{\circ} \mathrm{C}$ with Hib porin or loop L7 and then used for cell stimulation. U937 cells $\left(3 \times 10^{6}\right.$ cells $\left./ \mathrm{mL}\right)$ were stimulated for $10 \mathrm{~min}$, lysed and immunoprecipitated with anti-phosphospecific form antibodies of each enzyme. The immunoprecipitates were subjected to SDS-PAGE, blotted onto PVDF membrane and reacted with specific HRP conjugated antibodies.

Notes: Gels were scanned for densitometry analysis with the Sigma Gel Software, and the ratio of the value for each stimulation to the value for protein P2, which was taken as $100 \%$, is shown. The data are averages from three different experiments; the error bars indicate the standard errors of the means.

Peptide concentrations of $0.01 \mathrm{nmol} / \mathrm{mL}, 0.05 \mathrm{nmol} / \mathrm{mL}$, $0.13 \mathrm{nmol} / \mathrm{mL}, 5.0 \mathrm{nmol} / \mathrm{mL}, 12 \mathrm{nmol} / \mathrm{mL}$ and $26 \mathrm{nmol} / \mathrm{mL}$ were assayed. Regarding the entire protein, signals from active peptides were visible 3 minutes after treatment, with a phosphorylation peak at 10 minutes persisting for at least 20 minutes thereafter and going back to standard levels by 60 minutes (data not shown). A standard concentration of $0.13 \mathrm{nmol} / \mathrm{mL}$ and stimulation times of 10 minutes were chosen for subsequent experiments. The peptide concentrations used were not toxic for cells, and treatments did not induce any significant release of LDH in cell supernatants (data not shown).

All complementary peptides were almost unable to activate efficiently phosphorylation of MEK1/2 and ERK1/2, p38 and JNK (Figure 2A and B). When P2 porin or the peptide L7 were pre-incubated with complementary molecules, 
we did not observe significant activation, which indicated that the interaction of complementary peptides with the porin significantly reduces its ability to induce the activation of signaling pathways (Figure 2). We observed a significant reduction when $\mathrm{P} 2$ porin was treated with complementary peptides.

\section{Release of TNF- $\alpha$ and IL-6 in U937 cells}

Peptide L7, at a concentration of $130 \mathrm{nmol} / \mathrm{mL}$, induced significant TNF- $\alpha$ and IL- 6 cytokine responses compared to the entire P2 protein, as previously reported. ${ }^{23} \mathrm{We}$ showed only the treatment with peptide at a concentration of $130 \mathrm{nmol} / \mathrm{mL}$, which gave the highest increases in the release of both cytokines (Figure 3A and B). All four complementary peptides were unable to induce significantly the release of
TNF- $\alpha$ (Figure 3A) and IL-6 (Figure 3B), but they were able to drastically reduce the cytokine release induced by porin P2 or loop L7. In fact, the preincubation of complementary peptides with $\mathrm{P} 2$ porin or loop $\mathrm{L} 7$ before cell stimulation strongly influenced the release of cytokines by porin P2 and loop L7. All complementary peptides induced a significant reduction of the cytokines release caused by porin as well as L7. The amount of released cytokines TNF- $\alpha$ and IL-6 by $\mathrm{P} 2$ was reduced by approximately $80 \%$ in the presence of complementary peptides. The amount of cytokines released by peptide L 7 was lower than that released by porin P2, and when the treatment was performed with L 7 and complementary peptides, we observed a reduction in $\mathrm{L} 7$ cytokines release of approximately $60 \%$. The concentrations of peptides used, as well as the duration of the treatment, were not toxic for

A

TNF- $\alpha$ release

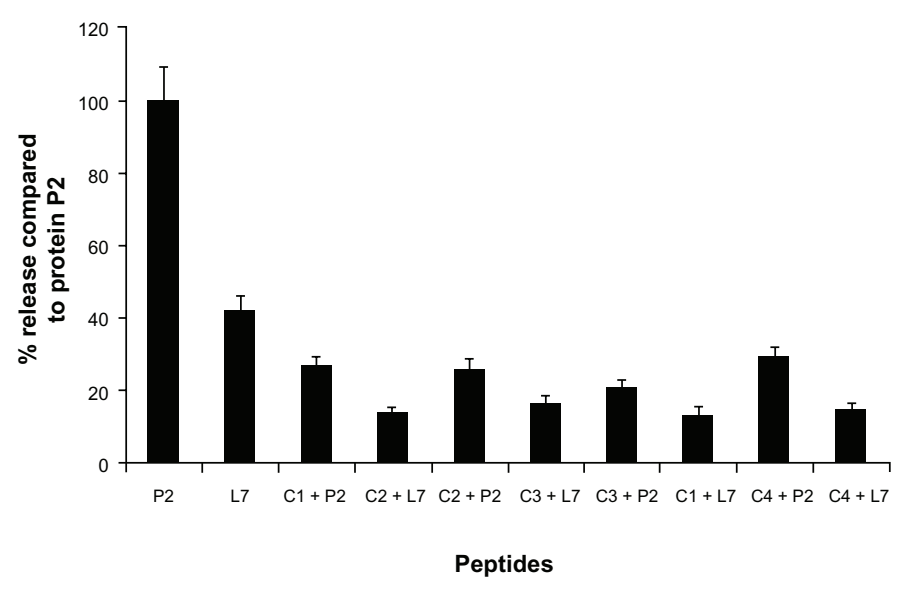

B

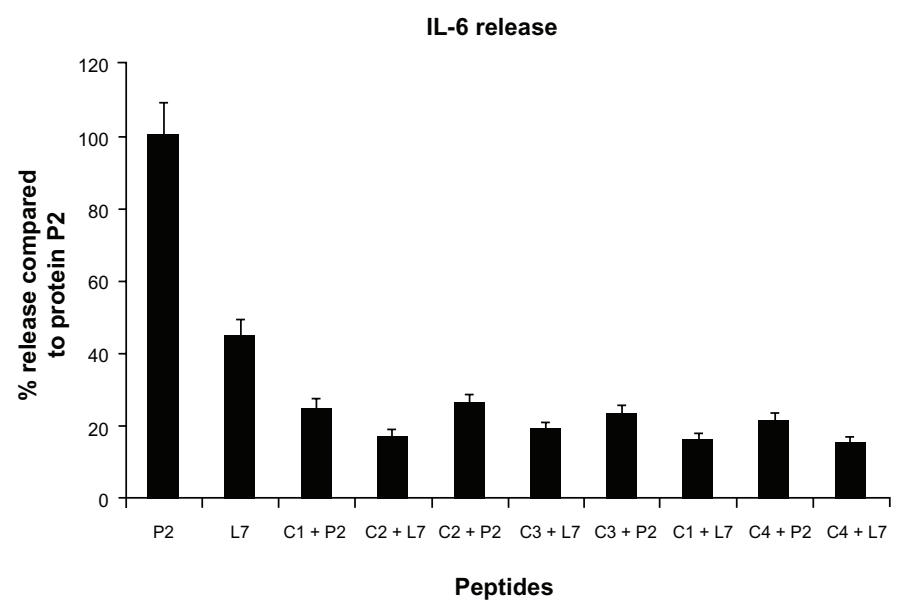

Figure 3 TNF- $\alpha$ (panel A) and IL-6 (panel B) release induced by loop L7 complementary peptides. U937 cells ( $3 \times 10^{6}$ cells $\left./ \mathrm{mL}\right)$ were stimulated with Hib porin ( 3 nmol/mL) or peptides $(130 \mathrm{nmol} / \mathrm{mL})$ for 24 hours at $37^{\circ} \mathrm{C}$ in $5 \% \mathrm{CO}_{2}$; in some assays, the complementary peptides $\mathrm{Cl}, \mathrm{C} 2, \mathrm{C} 3$ and $\mathrm{C} 4$ were preincubated for 60 minutes at $37^{\circ} \mathrm{C}$ with Hib porin or loop L7 and then used for U937-stimulation.

Notes: The results shown are the average of three independent experiments; the error bars indicate the standard errors of the means. 
the cells. In fact, the treatment did not induce any significant release of LDH in the cell supernatants (data not shown).

\section{Activation of AP-I and NF- $\kappa B$ in U937 cells}

The MAPK cascade activates transcription factors, such as activating protein 1 (AP-1) and nuclear factor $\kappa \mathrm{B}(\mathrm{NF}-\kappa \mathrm{B})$. It is well documented that LPS induces NF- $\kappa$ B activation in monocytes and regulates cytokine expression. ${ }^{39}$ It has been recently demonstrated that porins also induce the activation of AP-1 and NF- $\kappa$ B in U937 cells. ${ }^{40}$

In order to selectively analyze the regulation of loop L7 complementary peptides-induced AP-1 and NF- $\kappa$ B activation, an ELISA based Trans-Am technology from nuclear lysates of U937 cells stimulated by P2 porin, loop L7, or complementary peptides was performed. These transcription factors are presumed to be involved in the expression of proinflammatory cytokine genes. Therefore, in order to demonstrate AP-1 and NF- $\mathrm{BB}$ activation, we investigated the induction of AP-1 c-Fos/c-Jun subunits and NF- $\kappa \mathrm{B}$ p50/p65 subunits in whole-cell extracts using Abs specific for epitopes that are accessible only when the nuclear factors are phosphorylated and bound to their target DNA. Following the treatment of U937 cells with our stimuli, AP-1 and $\mathrm{NF}-\kappa \mathrm{B}$ binding significantly increased by 30 minutes, was maintained at the same level for 60 minutes, and returned to background levels by 120 minutes (data not shown). In particular, we found that P2 porin and loop L7 were able to activate significantly both AP-1 (Figure 4) and NF- $\mathrm{BB}$ (Figure 5).

When we tested the complementary peptides with porin P2 or with peptide loop L7, we observed a significant decrease in the production of AP-1 and NF- $\mathrm{KB}$ (Figures 4 and 5).

\section{Gel filtration}

Complex formation between P2 and complementary peptides was measured following the shift of the NBD moiety covalently linked to the N-terminal side of complementary peptides (Figure 6, panels B-E). The UV chromatographic profile at $210 \mathrm{~nm}$ detects the presence of both the peptide and the porin, whereas the profile at $465 \mathrm{~nm}$ is determined only by the presence of the NBD group linked to complementary peptides. In particular, we observed a specific binding for all the complementary peptides demonstrated by the elution of the peptides together with the porin P2 at lower retention times. The peptide $\mathrm{C} 4$ showed the lowest ability to bind to porin $\mathrm{P} 2$; while $\mathrm{C} 1$ and $\mathrm{C} 2$ showed the highest ability

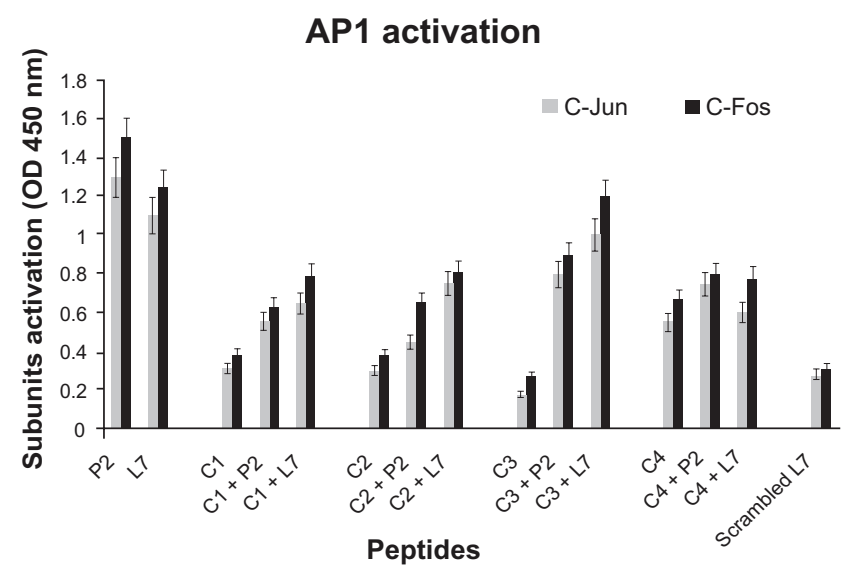

Figure 4 AP-I activation in presence of loop L7 complementary peptides. U937 cells $\left(10 \times 10^{6}\right.$ cells $\left./ \mathrm{mL}\right)$ were stimulated with Hib porin $(13 \mathrm{nmoL} / \mathrm{mL})$ or peptides $(130 \mathrm{nmol} / \mathrm{mL})$ for I hour at $37^{\circ} \mathrm{C}$ in $5 \% \mathrm{CO}_{2}$; in some assays, the complementary peptides $\mathrm{Cl}, \mathrm{C} 2, \mathrm{C} 3$ and $\mathrm{C} 4$ were preincubated for 60 min at $37^{\circ} \mathrm{C}$ with Hib porin or loop L7 and then used for U937-stimulation.

Notes: Cell lysates $(10 \mu \mathrm{g} / \mathrm{mL})$ were tested for binding of the activated c-Fos or c-Jun subunits to an AP-I consensus sequence using the Trans-Am AP-I ELISA kit. The experiment was performed in the presence of soluble wild-type or mutated consensus oligonucleotides. The results are expressed as specific binding (absorbance measured in the presence of the mutated oligonucleotide minus that measured in the presence of the wild-type oligonucleotide). The results are shown as means \pm standard errors of triplicate determinations.

as demonstrated by the higher elution peak of the peptide together with porin P2 at lower retention times (Figure 6, panels A-E). As a control of specificity, we used the porin OMP-C from Salmonella typhymurium (Figure 6, panels G-M), and we could not detect the formation of any significant complex. In order to determine whether the interaction

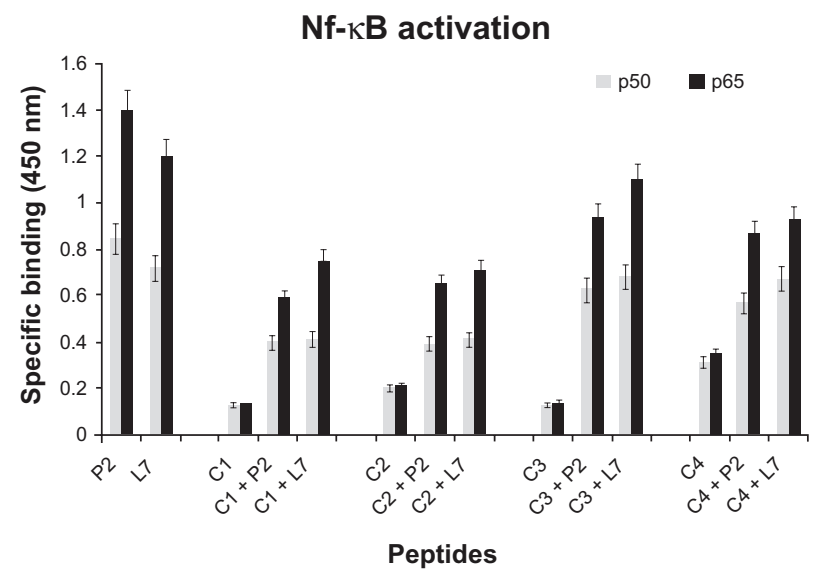

Figure 5 NF- $\kappa B$ activation in presence of loop L7 complementary peptides. U937 cells $\left(10 \times 10^{6}\right.$ cells $\left./ \mathrm{mL}\right)$ were stimulated with Hib porin $(13 \mathrm{nmol} / \mathrm{mL})$ or peptides $(130 \mathrm{nmol} / \mathrm{mL})$ for I hour at $37^{\circ} \mathrm{C}$ in $5 \% \mathrm{CO}_{2}$; in some assays, the complementary peptides $\mathrm{Cl}, \mathrm{C} 2, \mathrm{C} 3$ and $\mathrm{C} 4$ were preincubated for 60 minutes at $37^{\circ} \mathrm{C}$ with Hib porin or loop L7 and then used for U937-stimulation.

Notes: Cell lysates were tested for binding of the activated $p 50$ or $p 65$ subunits to an NF- $\kappa B$ consensus sequence using the Trans-Am NF- $\kappa B$ ELISA kit. The experiment was performed in the presence of soluble wild-type or mutated consensus oligonucleotides. The results are expressed as specific binding (absorbance measured in the presence of the mutated oligonucleotide minus that measured in the presence of the wild-type oligonucleotide). The results are shown as means \pm standard errors of triplicate determinations. 
A

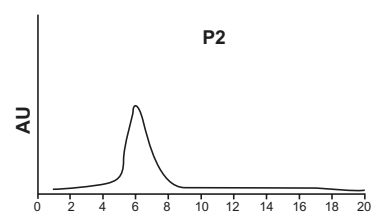

B

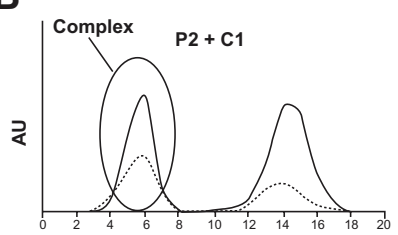

C

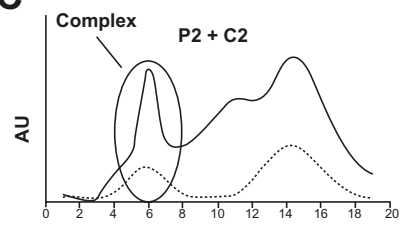

D

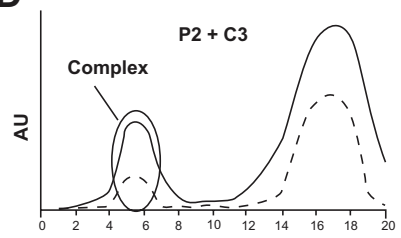

E

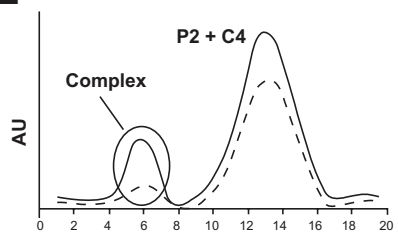

$\mathbf{F}$

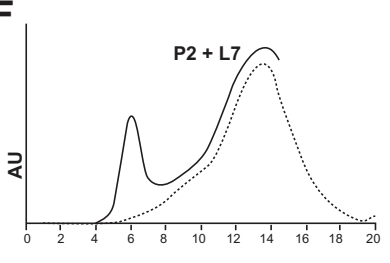

G

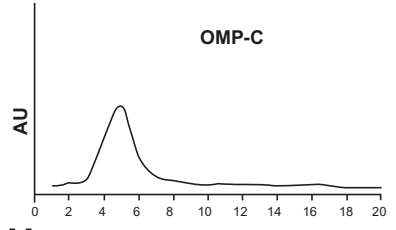

H

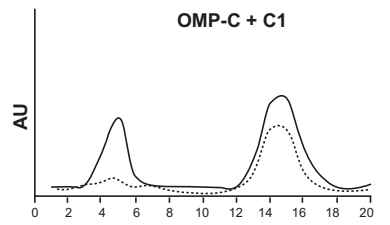

I

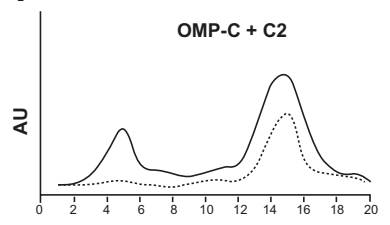

$\mathbf{L}$

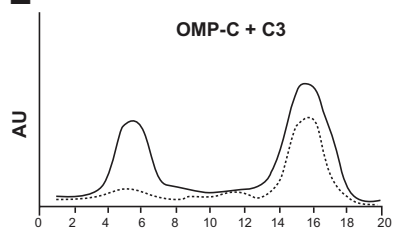

M

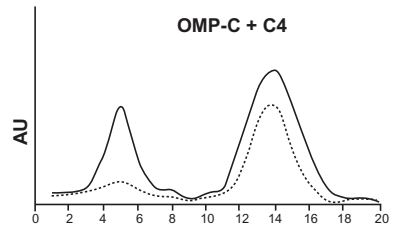

$\mathbf{N}$

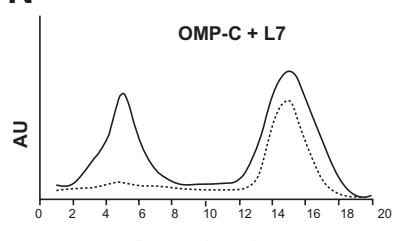

C1

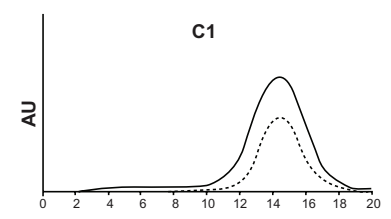

$\mathbf{P}$

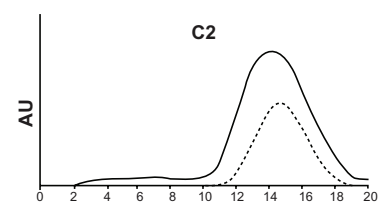

Q

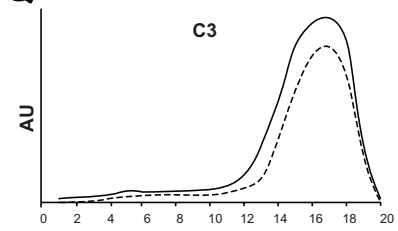

$\mathbf{R}$

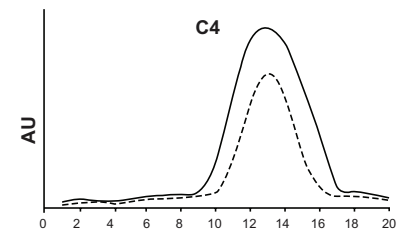

S

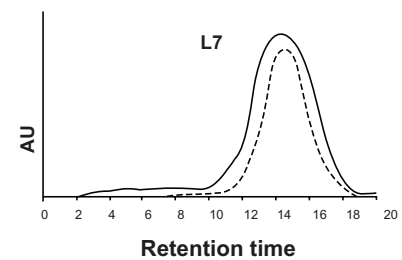

Figure 6 Binding of complementary peptides to porin P2 and OMPC by gel filtration. Peptides $\mathrm{Cl}, \mathrm{C2}, \mathrm{C} 3, \mathrm{C} 4$ and L7 (panels $\mathbf{O}-\mathbf{S}$ ) were mixed to porin P2 (panels $\mathbf{A}-\mathbf{F}$ ) or porin OMPC (panels $\mathbf{G}-\mathbf{N}$ ) with a molar ratio protein/peptide of $1 / 50$.

Notes: The binding mixture was held for I hour at $37^{\circ} \mathrm{C}$ and then was loaded on a PD-10 column containing Sephadex G-25 medium. The collected fractions were analyzed by UV spectrometry and the chromatographic profile obtained at $210 \mathrm{~nm}$ and $465 \mathrm{~nm}$ is shown.

was specific, we also used the peptide L7 as a control. We did not detect the formation of any complex in that case as shown by the absence of absorbance at $465 \mathrm{~nm}$ in the fraction at low retention times where the porin is eluted (Figure 6, panels $\mathrm{F}$ and $\mathrm{N}$ ).

\section{Discussion}

Porins possess a variety of proinflammatory and immunological activities, as shown for Salmonella typhimurium, ${ }^{40-43}$ Pasteurella multocida, Mannheimia haemolytica, ${ }^{41,44}$ and
Haemophilus influenza. ${ }^{21,23,28,41}$ Previous reports have demonstrated that porin-stimulated monocytic cell lines are activated with an evident phosphorylation of many cellular proteins. Some proteins were identified as MAPK and as nuclear transcription factors NF- $\mathrm{KB}, \mathrm{AP}-1$ and STAT-1/ STAT-3. Among the different surface bacterial components, Hib porin is involved in the pathogenesis of bacterial meningitis. ${ }^{28}$

The damage due to Gram-negative bacteria is a disorder thought to be caused by the excessive stimulation of 
mononuclear cells by active surface components of bacterial cells. Among those components, LPS has been studied most frequently, and several molecules have been analyzed for their antagonist activity against LPS. No research has attempted to find antagonists to porins. Loop 7 of porin P2 of Hib has been shown to stimulate the MAPKs pathway, similarly to porin $\mathrm{P} 2$, and thus play a key role in inflammation. We report a novel use of the complementary peptide approach to devise a peptide molecule able to bind selectively to the porin P2 of Hib, thereby inhibiting the activation of the MAPKs pathway. We aimed to show that the hydropathic complementarity in itself might be sufficient to develop an antagonist peptide to surface exposed loops, which could inhibit sequences that are involved in the host-pathogen interaction. Complementary peptides could be useful for drug discovery and therefore represent a conceptually attractive approach. There are some examples reported in the literature, ${ }^{14,45}$ which suggest that interactions between sense and antisense peptides could play an important role in the molecular interactions involved in the recognition between proteins. In addition to H-bonds, peptides provide various non-covalent interactions, which are strongly dependent on the peptide sequence; thus, the recognition is specific and selective. The successful applications of this principle for designing sequence-directed recognition peptides indicate that hydropathical complementarity plays an important role in peptide interactions. ${ }^{14,45}$

We employed the degeneracy of the antisense peptide approach to design complementary peptides to one of the surface exposed loops of porin P2 from Haemophilus influenzae. We showed that a biologically active peptide can be obtained from a small loop structure. In summary, the complementary peptides described were shown to bind specifically to porin P2 and to inhibit the MEK1/2 pathway and cytokine production. Complementary peptides could form the basis of a novel therapeutic approach against Gram-negative bacteria. The specificity of the mechanism was demonstrated by the failure of any other peptide tested to yield similar results. The approach of complementary peptides has been successfully used only for a few targets and is complicated by the possibility of peptides to interact non-specifically with the target protein. Our experiments support the use of this strategy for our target because in vivo porins are embedded in the outer membrane of the bacteria and only surface loops are available for the interaction. We thus proved that amphiphilic sequences complementary to surface exposed loops may represent a valuable strategy for reducing the inflammation caused by Gram-negative porins. Their noncovalent mode of interaction with the active loops of the porin P2 involve both hydrophobic and polar interactions.

\section{Conclusion}

The results of this study demonstrate the utility of an algorithmbased approach for the identification of independent biologically active peptides for a target that has clear therapeutic potential for bacterial infections. ${ }^{46}$ Agents that interfere with ligand binding and/or the formation of the higher order complexes might have therapeutic potential and/or be useful biological tools. In this context, biologically active peptides might be developed as specific antagonist of loop L7. In this study, we designed amphiphilic peptides complementary to loop L7, which may be used to block porin activity and may provide new opportunities for the design of novel agents that could be added to existing therapeutic strategies. Moreover, this study may represent a novel approach for the design of antibacterial molecules against other Gram-negative bacteria. Finally, this approach may be of interest in understanding the specific intermolecular interactions between pathogenic bacteria and their eukaryotic hosts, which underlie life-threatening diseases, such as septic shock.

\section{Acknowledgments}

This work was supported by MIUR (FIRB Prot. RBRN07BMCT). We thank Mr Leopoldo Zona for excellent technical assistance.

\section{Disclosure}

The authors report no conflicts of interest in this report.

\section{References}

1. Stein RA, Staros JV. Evolutionary analysis of the ErbB receptor and ligand families. J Mol Evol. 2000;50(5):397-412.

2. Ren Y, Blaker M, Seshadri L, McBride EW, Beinborn M, Kopin AS. Conserved cholecystokinin receptor transmembrane domain IV amino acids confer peptide affinity. J Mol Neurosci. 2003;20(2):115-124.

3. Selz KA, Samoylova TI, Samoylov AM, Vodyanoy VJ, Mandell AJ. Designing allosteric peptide ligands targeting a globular protein. Biopolymers. 2007;85(1):38-59.

4. Baranyi L, Campbell W, Ohshima K, Fujimoto S, Boros M, Okada H. The antisense homology box: a new motif within proteins that encodes biologically active peptides. Nat Med. 1995;1(9):894-901.

5. Blalock JE. Genetic origins of protein shape and interaction rules. Nat Med. 1995;1(9):876-878.

6. Bost KL, Blalock JE. Production of anti-idiotypic antibodies by immunization with a pair of complementary peptides. J Mol Recognit. 1989;1(4):179-183.

7. Rovati GE, Merli S, Schwarz S. Identification of hydropathically complementary putative contact sequences within epidermal growth factor (EGF) and the EGF receptor. Life Sci. 1992;51(1):37-47.

8. Araga S, LeBoeuf RD, Blalock JE. Prevention of experimental autoimmune myasthenia gravis by manipulation of the immune network with a complementary peptide for the acetylcholine receptor. Proc Natl Acad Sci U SA. 1993;90(18):8747-8751.

9. Ruiz-Opazo N, Akimoto K, Herrera VL. Identification of a novel dual angiotensin II/vasopressin receptor on the basis of molecular recognition theory. Nat Med. 1995;1(10):1074-1081.

10. Davids JW, El-Bakri A, Heal J, et al. Design of Antisense (Complementary) Peptides as Selective Inhibitors of Cytokine Interleukin-1. Angew Chem Int Ed Engl. 1997;36:6. 
11. Doherty P, Williams G, Williams EJ. CAMs and axonal growth: a critical evaluation of the role of calcium and the MAPK cascade. $M o l$ Cell Neurosci. 2000;16(4):283-295.

12. Heal JR, Roberts GW, Raynes JG, Bhakoo A, Miller AD. Specific interactions between sense and complementary peptides: the basis for the proteomic code. Chem Bio Chem. 2002;3(2-3):136-151.

13. Imai M, Baranyi L, Okada N, Okada H. Inhibition of HIV-1 infection by synthetic peptides derived CCR5 fragments. Biochem Biophys Res Commun. 2007;353(4):851-856.

14. Luo J, Zhang Q, Huang Y, Liu G, Zhao R. Quartz crystal microbalance biosensor for recombinant human interferon-beta detection based on antisense peptide approach. Anal Chim Acta. 2007;590(1):91-97.

15. Blalock JE, Smith EM. Hydropathic anti-complementarity of amino acids based on the genetic code. Biochem Biophys Res Commun. 1984;121(1):203-207.

16. Zhao R, Yu X, Liu H, et al. Study on the degeneracy of antisense peptides using affinity chromatography. $J$ Chromatogr A. 2001;913(1-2):421-428.

17. Achouak W, Heulin T, Pages JM. Multiple facets of bacterial porins. FEMS Microbiol Lett. 2001;199(1):1-7.

18. Galdiero M, Vitiello M, Galdiero S. Eukaryotic cell signaling and transcriptional activation induced by bacterial porins. FEMS Microbiol Lett. 2003;226(1):57-64

19. Naumann M, Rudel T, Meyer TF. Host cell interactions and signaling with Neisseria gonorrhoeae. Curr Opin Microbiol. 1999;2(1):62-70.

20. Galdiero S, Galdiero M, Pedone C. beta-Barrel membrane bacterial proteins: structure, function, assembly and interaction with lipids. Curr Protein Pept Sci. 2007;8(1):63-82.

21. Galdiero S, Capasso D, Vitiello M, D'Isanto M, Pedone C, Galdiero M. Role of surface-exposed loops of Haemophilus influenzae protein P2 in the mitogen-activated protein kinase cascade. Infect Immun. 2003;71(5):2798-2809.

22. Srikumar R, Dahan D, Gras MF, Ratcliffe MJ, van Alphen L, Coulton JW. Antigenic sites on porin of Haemophilus influenzae type b: mapping with synthetic peptides and evaluation of structure predictions. J Bacteriol. 1992;174(12):4007-4016.

23. Galdiero S, Vitiello M, Amodeo P, et al. Structural requirements for proinflammatory activity of porin P2 Loop 7 from Haemophilus influenzae. Biochemistry. 2006;45(14):4491-4501.

24. Severino V, Chambery A, Vitiello M, et al. Proteomic analysis of human U937 cell line activation mediated by Haemophilus influenzae type b P2 porin and its surface-exposed loop 7. J Proteome Res. 2010;9(2):1050-1062.

25. Vitiello M, Galdiero S, D’Isanto M, et al. Pathophysiological changes of gram-negative bacterial infection can be reproduced by a synthetic peptide mimicking loop L7 sequence of Haemophilus influenzae porin. Microbes Infect. 2008;10(6):657-663.

26. Galdiero M, Tortora A, Damiano N, Vitiello M, Longanella A, Galdiero E. Induction of cytokine mRNA expression in U937 cells by Salmonella typhimurium porins is regulated by different phosphorylation pathways. Med Microbiol Immunol. 2005;194(1-2):13-23.

27. Galdiero M, D'Amico M, Gorga F, et al. Haemophilus influenzae porin contributes to signaling of the inflammatory cascade in rat brain. Infect Immun. 2001;69(1):221-227.

28. Galdiero M, D’Isanto M, Vitiello M, Finamore E, Peluso L. Porins from Salmonella enterica serovar Typhimurium induce TNF-alpha, IL-6 and IL-8 release by CD14-independent and CD11a/CD18-dependent mechanisms. Microbiology. 2001;147(Pt 10):2697-2704.
29. Lowry OH, Rosebrough NJ, Farr AL, Randall RJ. Protein measurement with the Folin phenol reagent. J Biol Chem. 1951;193(1):265-275.

30. Laemmli UK. Cleavage of structural proteins during the assembly of the head of bacteriophage T4. Nature. 1970;227(5259):680-685.

31. Tsai CM, Frasch CE. A sensitive silver stain for detecting lipopolysaccharides in polyacrylamide gels. Anal Biochem. 1982;119(1):115-119.

32. Yin ET, Galanos C, Kinsky S, et al. Picogram-sensitive assay for endotoxin: gelation of Limulus polyphemus blood cell lysate induced by purified lipopolysaccharides and lipid A from Gram-negative bacteria. Biochim Biophys Acta. 1972;261(1):284-289.

33. Nikaido H, Rosenberg EY. Porin channels in Escherichia coli: studies with liposomes reconstituted from purified proteins. J Bacteriol. $1983 ; 153(1): 241-252$.

34. Rapaport D, Shai Y. Interaction of fluorescently labeled analogues of the amino-terminal fusion peptide of Sendai virus with phospholipid membranes. J Biol Chem. 1994;269(21):15124-15131.

35. Issekutz AC. Removal of gram-negative endotoxin from solutions by affinity chromatography. J Immunol Methods. 1983;61(3):275-281.

36. Renard P, Ernest I, Houbion A, et al. Development of a sensitive multi-well colorimetric assay for active NFkappaB. Nucleic Acids Res. 2001;29(4):E21.

37. Root-Bernstein RS. Amino acid pairing. J Theor Biol. 1982;94(4): 885-894.

38. Kyte J, Doolittle RF. A simple method for displaying the hydropathic character of a protein. J Mol Biol. 1982;157(1):105-132.

39. Yao J, Mackman N, Edgington TS, Fan ST. Lipopolysaccharide induction of the tumor necrosis factor-alpha promoter in human monocytic cells. Regulation by Egr-1, c-Jun, and NF-kappaB transcription factors. J Biol Chem. 1997;272(28):17795-17801.

40. Galdiero M, Vitiello M, Sanzari E, et al. Porins from Salmonella enterica serovar Typhimurium activate the transcription factors activating protein 1 and NF-kappaB through the Raf-1-mitogen-activated protein kinase cascade. Infect Immun. 2002;70(2):558-568.

41. Marcatili A, D'Isanto M, Galdiero M, et al. Role of Pasteurella multocida, Pasteurella haemolytica and Salmonella typhimurium porins on inducible nitric oxide release by murine macrophages. Res Microbiol. 2000;151(3):217-228.

42. Galdiero M, De Martino L, Marcatili A, Nuzzo I, Vitiello M, Cipollaro de 1'Ero G. Th1 and Th2 cell involvement in immune response to Salmonella typhimurium porins. Immunology. 1998;94(1):5-13.

43. Finamore E, Vitiello M, D'Isanto M, et al. Evidence for IL-6 promoter nuclear activation in U937 cells stimulated with Salmonella enterica serovar Typhimurium porins. Eur Cytokine Netw. 2009;20(3): $140-147$.

44. Iovane G, Pagnini P, Galdiero M, et al. Role of Pasteurella multocida porin on cytokine expression and release by murine splenocytes. Vet Immunol Immunopathol. 1998;66(3-4):391-404.

45. Fassina G, Cassani G, Gnocchi P, Fornasiero MC, Isetta AM. Inhibition of interleukin-2/p55 receptor subunit interaction by complementary peptides. Arch Biochem Biophys. 1995;318(1):37-45.

46. Galdiero M, Cantisani M, Tarallo R, Falanga A, Galdiero S. Septic Shock by Gram-Negative Infections: Role of Outer Membrane Proteins, in Severe Sepsis and Septic Shock - Understanding a Serious Killer, Dr Ricardo Fernandez (Ed.), 2012, ISBN: 978-953-307-950-9, InTech, 27-46

\section{Dovepress}

\section{Publish your work in this journal}

The International Journal of Nanomedicine is an international, peerreviewed journal focusing on the application of nanotechnology in diagnostics, therapeutics, and drug delivery systems throughout the biomedical field. This journal is indexed on PubMed Central, MedLine, CAS, SciSearch $\AA$, Current Contents ${ }^{\circledR} /$ Clinical Medicine,

Journal Citation Reports/Science Edition, EMBase, Scopus and the Elsevier Bibliographic databases. The manuscript management system is completely online and includes a very quick and fair peer-review system, which is all easy to use. Visit http://www.dovepress.com/ testimonials.php to read real quotes from published authors. 